\title{
Invariant Feeding Kinematics of Two Trophically Distinct Nonnative Florida Fishes, Belonesox belizanus and Cichlasoma urophthalmus across Environmental Temperature Regimes
}

\author{
Tyler J. Sloan ${ }^{1} \&$ Ralph G. Turingan ${ }^{1}$ \\ ${ }^{1}$ Department of Biological Sciences, Florida Institute of Technology, Melbourne, USA \\ Correspondence: Tyler Sloan, Department of Biological Sciences, Florida Institute of Technology, Melbourne, \\ FL 32901, USA. Tel: 1-781-243-1241. E-mail: tsloan2009@my.fit.edu
}

Received: August 22, 2012 Accepted: September 15, 2012 Online Published: September 26, 2012

doi:10.5539/ijb.v4n4p117 URL: http://dx.doi.org/10.5539/ijb.v4n4p117

\begin{abstract}
Nonnative fishes have the ability to adapt to environmental conditions in the invaded ecosystem and utilize resources that may have been absent in their native ecosystem. Belonesox belizanus and Cichlasoma urophthalmus are both nonnative fishes in Florida. Ecomorphological studies conclude that $C$. urophthalmus is a trophic generalist while B. belizanus is a trophic specialist. The current Florida distribution of these species indicates that $C$. urophthalmus spreads northerly into the colder regions of Florida at a faster rate than $B$. belizanus. Is it conceivable that this variation in rate of spread is due to differences in temperature response between these ecomorphologically distinct nonnative fishes? This study was designed to test the hypothesis that the prey-capture kinematics and behavior differ between $C$. urophthalmus and B. belizanus at a given temperature and across temperatures. Two-Way Repeated Measures Multivariate Analysis of Covariance (MANCOVAR) revealed that (1) at a given temperature, excursion and timing variables differed between species and (2) the kinematics of prey-capture did not vary across temperatures in both species. This interspecific comparison suggests that both species have the same temperature tolerance and that any difference in their rate of spread across Florida may be driven by factors other than species-specific physiological tolerance to temperature.
\end{abstract}

Keywords: Cichlasoma urophthalmus, Belonesox belizanus, invasive species, specialist, generalist

\section{Introduction}

The ecological impacts of nonnative fishes in invaded ecosystems are well documented: they spread diseases and carry pathogens (Weinstein et al., 1997; Britton, Davies, Brazier, \& Pinder, 2006; Gozlan, St-Hilaire, Feist, Martin, \& Kent, 2005), alter native-fish community structure (Crowder, 1984; Douglas, Marsh, \& Minckley, 1994; Singh, Pathak, \& Lakra, 2010), wrought changes in trophic dynamics (Mooney \& Cleland, 2001; Perry, Lodge, \& Feder, 2002; Sato et al., 2010), establish more tolerant hybrid populations (Miley, 1978; Ogutu-Ohwayo, 1990; Bacheler, Neal, \& Noble, 2004), and reduce biodiversity, ultimately driving biological homogenization (McKinney \& Lockwood, 1999; Rahel, 2007; Sato et al., 2010). In addition to the biological and ecological impacts of nonnative species, local and national economies have been negatively impacted by the proliferation of invasive species. For example, in the United States of America, the cost of nonnative species, largely from loss of revenue is estimated at over 120 billion US dollars annually (Pimentel, Zuniga, \& Morrison, 2005). Knowledge of the potential ecological and economic consequences of species invasions continue to stimulate research on the underlying mechanisms that drive the spread of nonnative species in their invaded ecosystem.

One interesting facet of invasive-species research is the elucidation of the response of nonnative species to environmental temperature. This is particularly underscored by our continuing search for information that furthers our understanding of the adaptive response of populations to climate change (Davis \& Shaw, 2001; Baker, McClanahan, \& Glynn, 2004; Charmantier et al., 2008). The response of organisms to environmental temperature is rooted from its influence on physiological processes that alter functional performance. For example, it is well known that metabolic rate is directly proportional to environmental temperature (Cossins \& Bowler, 1987; Clarke \& Johnston, 1999; Gillooly, Brown, West, \& Savage, 2001) and the contractile property of 
skeletal muscle is altered by temperature (Rome \& Sosnicki, 1990; Josephson, 1993; Watabe, 2002; Malek, Saiadi, Abraham, Grundy, \& Gerhard, 2004). In fishes and other ectotherms, environmental temperature has profound effects on swimming (Rome, Swank, \& Coughlin, 2000; Herbing, 2002; Lee et al., 2003; Green \& Fisher, 2004) and feeding (Wintzer \& Motta, 2004; DeVries \& Wainwright, 2006) performance. As poikilotherms, individual fishes have a range of temperature that is optimal for their physiological performance, thus, environmental temperature is one of the most important abiotic factors that limit the distribution of fish populations (Shafland \& Pestrak, 1982; Rome \& Sosnicki, 1990; Wintzer \& Motta, 2004; DeVries \& Wainwright, 2006).

Most of what is known about the effects of temperature on the feeding kinematics of fishes is based on experiments that determined immediate responses to acute temperature change in their native range (Wintzer \& Motta, 2004; DeVries \& Wainwright, 2006). Wintzer and Motta, (2004) concluded that in bluegill (Lepomis macrochirus) subjected to a $6^{\circ} \mathrm{C}$ change in temperature within 48 hours, several timing variables including time to maximum gape and time to maximum lower jaw depression increased as water temperature decreased. Likewise, DeVries and Wainwright (2006) found that a $6-9^{\circ} \mathrm{C}$ change in temperature within an hour to ten hours caused the time to reach maximum gape in Micropterus salmoides increase with decreasing temperature. In this study, we determined for the first time, the effect of temperature on the prey-capture kinematics of nonnative fishes. In addition, the response of two nonnative fishes with contrasting food habits to temperature was investigated.

Pike killifish, Belonesox belizanus (Poeciliidae), a Mexican and Central American native species was introduced in south Florida in the late 1950s and has been identified as one of the most abundant nonnative fishes in Florida (Hubbs, 1936; Rosen \& Bailey, 1963; Belshe, 1961; Miley, 1978; Anderson, 1980; Kerfoot, Lorenz, \& Turingan, 2011). It is characterized as a specialist predator, with an oral-jaw apparatus well designed for piscivory. Pike killifish achieves a large gape formed by the elongated premaxilla and the mandible, lined with large unicuspid teeth (Greven \& Brenner, 2008; Ferry-Graham, Hernandez, Gibb, \& Pace, 2010). The ability of pike killifish to independently rotate its premaxilla posterodorsally, facilitated by the premaxillomandibular ligament and a twisting maxilla, further enhances gape (Ferry-Graham et al., 2010) (Figure 1).

Mayan cichlid, Cichlasoma urophthalmus, native to waters ranging from eastern Mexico to Nicaragua (Miller, 1966) manifests the traits of a typical invasive species, including tolerance to extreme variations in salinity (Martinez-Palacios, Ross, \& Rosado-Vallado, 1990; Stauffer \& Boltz, 1994; Schofield, Loftus, \& Fontaine, 2009) and temperature (Marinez-Palacios \& Ross, 1992; Stauffer \& Boltz, 1994). In addition, gut content analysis revealed that $C$. urophthalmus has a generalist diet, feeding on detritus, plants, invertebrates and fish (Martinez-Palacios \& Ross, 1988; Chávez-López, Peterson, Brown-Peterson, Morales-Gomez, \& Franco-Lopez, 2005; Bergmann \& Motta, 2005; Hellig, Kerschbaumer, Sefc, \& Koblmüller, 2010). Like other species of the family Cichlidae, the Mayan cichlid has a generalized fish oral jaw mechanism for prey capture and well developed pharyngeal jaws for prey-processing (Hulsey, 2006).

Both pike killifish and Mayan cichlid have continued to spread northerly from their point of introduction in south Florida toward the colder regions of Florida (Belshe, 1961; Miley, 1978; Anderson, 1980; Kerfoot et al., 2011).The average annual temperature within the current distribution of both nonnative fishes ranges between $20^{\circ} \mathrm{C}$ and $30^{\circ} \mathrm{C}$ (http://www.nodc.noaa.gov/dsdt/cwtg/all.html). Preliminary experiments in the laboratory indicated that fishes exposed to temperature lower than $20^{\circ} \mathrm{C}$ did not eat. The inherent effects of temperature on the contractile properties of muscles that drive prey-capture kinematics and on the physical properties of water that affect predator and prey behaviors serve as the premise for testing two hypotheses: at a given temperature $\left(20^{\circ} \mathrm{C}, 25^{\circ} \mathrm{C} \& 30^{\circ} \mathrm{C}\right)$ the prey-capture kinematics differ between both nonnative fish species, and the prey-capture kinematics of each nonnative fish species vary across temperatures.

\section{Materials and Methods}

Four B. belizanus, collected from the Florida Everglades National Park and four C. urophthalmus, collected from Merritt Island, Florida were acclimated and trained for high-speed filming in the fish ecophysiology laboratory at Florida Institute of Technology. Each fish was housed in 381 filming tanks filled with $24 \mathrm{ppt}$ (for C. urophthalmus) and 0 ppt (B. belizanus) water, and then filmed at $20^{\circ} \mathrm{C}, 25^{\circ} \mathrm{C}$ and $30^{\circ} \mathrm{C}$. Temperature was raised from $20^{\circ} \mathrm{C}$ to the higher filming temperatures at a rate of $1^{\circ} \mathrm{C}$ daily using a water heater. Each fish was filmed using a RedLake High-Speed Motionscope 2000S camera with a shutter speed of 1/1000s at 250 frames $\mathrm{s}^{-1}$ while feeding on live mosquito fish (Gambusia holbrooki), a natural prey for both species. Feeding sessions were recorded every other day and fish were not fed in between recording sessions. At least four feeding bouts were recorded for each fish. Four films were analyzed per fish at each of the three experimental temperatures using MaxTRAQ (Version 


\subsubsection{Innovision Systems, Inc.).}

Each film was played back frame-by-frame to measure eight kinematic variables used to compare prey-capture kinematics between the two nonnative species and among three temperature regimes. The four displacement-kinematic variables are defined in Table 1 and Figure 1. Time to reach the maximum displacement-kinematic variables defined in Table 1 namely time (ms) to maximum gape, hyoid depression, and cranial rotation were measured relative to the frame prior to mouth opening.

Table 1. Kinematic variable descriptions

\begin{tabular}{ll}
\hline Kinematic Variable & Description \\
\hline Maximum Gape (mm) & $\begin{array}{l}\text { Maximum distance measured from the anteriormost tip of } \\
\text { the premaxilla to the anteriormost tip of the dentary when } \\
\text { the mouth is open. Points (A) to (C). }\end{array}$ \\
Maximum Hyoid Depression (mm) & $\begin{array}{l}\text { Maximum length measured from the center of the eye to } \\
\text { the anteriormost point of the mouth at full depression. } \\
\text { Points (E) to (D). }\end{array}$ \\
Maximum Lower Jaw Angular Displacement & $\begin{array}{l}\text { Maximum rotation of the lower jaw measured by the line } \\
\text { segments AB to BC. }\end{array}$ \\
Maximum Cranial Rotation (degree) & $\begin{array}{l}\text { Maximum rotation of the neurocranium dorsally and } \\
\text { posteriorly, measured by the angle formed from line } \\
\text { segments AG to GF. }\end{array}$
\end{tabular}

Table 1 shows definition and measurement of the excursion-kinematic variables used to examine variation in feeding performance between species and across temperatures. Identified hotspots are illustrated in Figure 1.

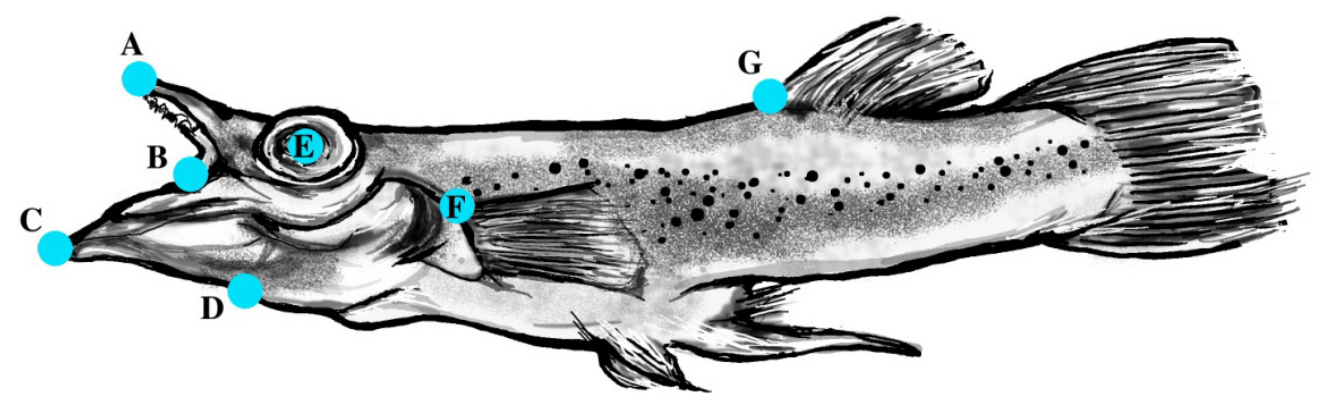

Figure 1. Diagram of a pike killifish, B. belizanus, showing the hotspots used in defining and measuring the excursion-kinematic variables identified in Table 1. Corresponding homologous hotspots were used in the Mayan cichlid, C. urophthalmus

To test the above-stated research hypotheses, the kinematic variables were $\log _{10}$-transformed and subjected to a 2-way Repeated Measures Multivariate Analysis of Covariance (MANCOVAR) with species and temperature as the main effects, the eight kinematic measurements as the dependent variables and fish standard length as the covariate.

\section{Results}

Both species of nonnative fishes fed aggressively at $20^{\circ} \mathrm{C}, 25^{\circ} \mathrm{C}$, and $30^{\circ} \mathrm{C}$. In general, B. belizanus approached the prey slowly and as soon as the prey was within $30 \mathrm{~mm}$ of the predator, B. belizanus lunged toward the prey, opened its mouth widely and snapped at the prey. In contrast, $C$. urophthalmus behaved more aggressively; as soon as the prey was introduced into the filming tank, C. urophthalmus rapidly swam toward the prey and suction-fed on the prey instantaneously. Initial examination of the kinematic variables indicates that $B$. belizanus achieves a greater maximum gape than that of $C$. urophthalmus (Table 2). In contrast, the lower jaw of $C$. urophthalmus rotated to a much higher angular displacement compared to that of $B$. belizanus. Time to reach these maximum kinematic values appear consistently across the three temperature treatments. The MANCOVAR revealed that prey-capture kinematics varied between species $\left(\mathrm{F}_{1,64}=7.32 ; \mathrm{P}=0.009\right)$, but, remained consistent 
across temperature $\left(\mathrm{F}_{2,64}=0.070 ; \mathrm{P}=0.933\right)$ (Table 3). Fish standard length had no confounding effect on kinematic performance $\left(\mathrm{F}_{1,64}=0.061 ; \mathrm{P}=0.328\right)$ (Table 3$)$. Post-hoc univariate hypothesis test revealed that all of the kinematic variables differed between the two species (Table 4). Prey-capture kinematics in both species is invariant across temperature (Table 5).

Table 2. Mean and Standard Error of the Mean (S.E.M.) of kinematic variables

\begin{tabular}{|c|c|c|c|c|c|c|c|}
\hline \multirow{2}{*}{\multicolumn{2}{|c|}{$\begin{array}{l}\text { Kinematic } \\
\text { Variable } \\
\text { Maximum Gape }(\mathrm{mm})\end{array}$}} & \multicolumn{2}{|c|}{$\begin{array}{l}20^{\circ} \mathrm{C} \\
\text { Mean } \pm \text { S.E.M. }\end{array}$} & \multicolumn{2}{|c|}{$\begin{array}{l}25^{\circ} \mathrm{C} \\
\text { Mean } \pm \text { S.E.M. }\end{array}$} & \multicolumn{2}{|c|}{$\begin{array}{l}30^{\circ} \mathrm{C} \\
\text { Mean } \pm \text { S.E.M. }\end{array}$} \\
\hline & & $\mathrm{P}$ & $17.16 \pm 1.67$ & $\mathrm{P}$ & $18.30 \pm 2.32$ & $\mathrm{P}$ & $17.20 \pm 1.65$ \\
\hline & $\mathrm{M}$ & $14.84 \pm 0.44$ & $\mathrm{M}$ & $13.91 \pm 0.29$ & M & $11.83 \pm 2.01$ \\
\hline \multirow{2}{*}{\multicolumn{2}{|c|}{$\begin{array}{l}\text { Time to Maximum Gape } \\
(\mathrm{ms})\end{array}$}} & $\mathrm{P}$ & $14.33 \pm 1.92$ & $\mathrm{P}$ & $12.67 \pm 0.39$ & $\mathrm{P}$ & $27.00 \pm 8.65$ \\
\hline & & $\mathrm{M}$ & $33.56 \pm 5.29$ & $\mathrm{M}$ & $30.67 \pm 1.84$ & $\mathrm{M}$ & $26.22 \pm 4.62$ \\
\hline \multirow{2}{*}{\multicolumn{2}{|c|}{$\begin{array}{l}\text { Maximum } \\
\text { Depression (mm) }\end{array}$}} & $\mathrm{P}$ & $5.035 \pm 0.32$ & $\mathrm{P}$ & $6.55 \pm 0.96$ & $\mathrm{P}$ & $5.28 \pm 0.66$ \\
\hline & & $\mathrm{M}$ & $4.10 \pm 0.26$ & $\mathrm{M}$ & $4.05 \pm 0.18$ & $\mathrm{M}$ & $3.68 \pm 0.60$ \\
\hline \multirow{2}{*}{\multicolumn{2}{|c|}{$\begin{array}{l}\text { Time to Maximum Hyoid } \\
\text { Depression (ms) }\end{array}$}} & $\mathrm{P}$ & $18.00 \pm 2.28$ & $\mathrm{P}$ & $17.89 \pm 0.46$ & $\mathrm{P}$ & $32.33 \pm 8.95$ \\
\hline & & M & $29.89 \pm 4.24$ & M & $43.22 \pm 2.65$ & M & $25.78 \pm 3.48$ \\
\hline \multirow{2}{*}{\multicolumn{2}{|c|}{$\begin{array}{l}\text { Maximum } \\
\text { Rotation (degree) }\end{array}$}} & $\mathrm{P}$ & $20.064 \pm 4.08$ & $\mathrm{P}$ & $16.94 \pm 1.86$ & $\mathrm{P}$ & $20.58 \pm 1.70$ \\
\hline & & $\mathrm{M}$ & $37.38 \pm 2.01$ & $\mathrm{M}$ & $42.05 \pm 1.28$ & $\mathrm{M}$ & $38.89 \pm 0.46$ \\
\hline \multirow{2}{*}{\multicolumn{2}{|c|}{$\begin{array}{l}\text { Time to Maximum Cranial } \\
\text { Rotation (ms) }\end{array}$}} & $\mathrm{P}$ & $16.67 \pm 2.07$ & $\mathrm{P}$ & $13.78 \pm 1.59$ & $\mathrm{P}$ & $32.83 \pm 9.25$ \\
\hline & & $\mathrm{M}$ & $5.33 \pm 0.54$ & $\mathrm{M}$ & $4.78 \pm 0.64$ & $\mathrm{M}$ & $4.83 \pm 0.83$ \\
\hline \multirow{2}{*}{$\begin{array}{l}\text { Maximum } \\
\text { Angular } \\
\text { (degree) }\end{array}$} & \multirow{2}{*}{$\begin{array}{l}\text { Lower Jaw } \\
\text { Displacement }\end{array}$} & $\mathrm{P}$ & $83.91 \pm 8.03$ & $\mathrm{P}$ & $84.16 \pm 2.92$ & $\mathrm{P}$ & $84.92 \pm 1.18$ \\
\hline & & $\mathrm{M}$ & $171.52 \pm 5.32$ & $\mathrm{M}$ & $170.68 \pm 3.39$ & $\mathrm{M}$ & $164.23 \pm 7.12$ \\
\hline \multirow{2}{*}{$\begin{array}{l}\text { Time to } \\
\text { Angular } \\
(\mathrm{ms})\end{array}$} & \multirow{2}{*}{$\begin{array}{l}\text { Lower Jaw } \\
\text { Displacement }\end{array}$} & $\mathrm{P}$ & $14.33 \pm 1.92$ & $\mathrm{P}$ & $13.44 \pm 0.56$ & $\mathrm{P}$ & $26.83 \pm 8.67$ \\
\hline & & M & $29.78 \pm 5.93$ & M & $34.67 \pm 0.48$ & M & $25.39 \pm 6.27$ \\
\hline
\end{tabular}

$\mathrm{P}=$ Pike killifish, Belonesox belizanus; $\mathrm{M}=$ Mayan cichlid, Cichlasoma urophthalmus.

Table 2 shows the Mean and Standard Error of the Mean (S. E. M.) of the eight kinematic variables used to examine variation in feeding kinematics between species and across environmental temperature regimes.

Table 3. Results of the Two-Way Repeated Measures Multivariate Analysis of Covariance (MANCOVAR)

\begin{tabular}{llllll}
\hline Source of Variation & SS & df & Mean Squares & F-Ratio & p-Value \\
\hline Species & 0.46 & 1 & 0.46 & 7.32 & 0.009 \\
Temperature & 0.004 & 2 & 0.004 & 0.07 & 0.933 \\
Standard Length (SL) & 0.06 & 1 & 0.061 & 0.098 & 0.328 \\
Error & 0.062 & 64 & 0.062 & - & - \\
\hline
\end{tabular}

Table 3 shows the results of the Two-Way Repeated Measures Multivariate Analysis of Covariance (MANCOVAR) on the eight kinematic variables used to examine variation in feeding kinematics between species and across environmental temperature regimes. 
Table 4. Results of the Post-MANCOVAR Hypothesis Test

\begin{tabular}{llllll}
\hline Source & SS & df & Mean Squares & F-Ratio & p-Value \\
\hline Maximum Gape (mm) & 0.20 & 1 & 0.20 & 22.82 & 0.000 \\
Error & 0.57 & 64 & 0.009 & - & - \\
Time to Maximum Gape (ms) & 1.006 & 1 & 1.006 & 34.54 & 0.000 \\
Error & 1.86 & 64 & 0.029 & - & - \\
Maximum Hyoid Depression (mm) & 0.36 & 1 & 0.36 & 18.94 & 0.000 \\
Error & 1.20 & 64 & 0.019 & - & - \\
Time to Maximum Hyoid Depression (ms) & 0.42 & 1 & 0.42 & 17.64 & 0.000 \\
Error & 1.50 & 64 & 0.024 & - & - \\
Maximum Cranial Rotation (degree) & 1.64 & 1 & 1.64 & 155.98 & 0.000 \\
Error & 0.67 & 64 & 0.01 & - & - \\
Time to Maximum Cranial Rotation (ms) & 3.92 & 1 & 3.92 & 84.34 & 0.000 \\
Error & 2.98 & 64 & 0.046 & - & - \\
Maximum Lower Jaw Angular Displacement (degree) & 1.25 & 1 & 1.23 & 465.75 & 0.000 \\
Error & 0.17 & 64 & 0.003 & - & - \\
Time to Maximum Lower Jaw Angular Displacement (ms) & 0.80 & 1 & 0.80 & 24.089 & 0.000 \\
Error & 2.123 & 64 & 0.033 & - & - \\
\hline
\end{tabular}

Table 4 shows results of the Post-MANCOVAR Hypothesis Test to determine the relative contribution of species-effect to the variation of prey-capture kinematics between $B$. belizanus and C. urophthalmus.

Table 5. Results of the Post-MANCOVAR Hypothesis Test

\begin{tabular}{llllll}
\hline Source & SS & df & Mean Squares & F-Ratio & p-Value \\
\hline Maximum Gape (mm) & 0.058 & 2 & 0.029 & 3.25 & 0.045 \\
Error & 0.57 & 64 & 0.009 & - & - \\
Time to Maximum Gape (ms) & 0.028 & 2 & 0.014 & 0.48 & 0.622 \\
Error & 1.86 & 64 & 0.029 & - & - \\
Maximum Hyoid Depression (mm) & 0.06 & 2 & 0.032 & 1.72 & 0.187 \\
Error & 1.20 & 64 & 0.019 & - & - \\
Time to Maximum Hyoid Depression (ms) & 0.10 & 2 & 0.050 & 2.12 & 0.129 \\
Error & 1.52 & 64 & 0.024 & - & - \\
Maximum Cranial Rotation (degree) & 0.036 & 2 & 0.018 & 1.72 & 0.187 \\
Error & 0.67 & 64 & 0.010 & - & - \\
Time to Maximum Cranial Rotation (ms) & 0.30 & 2 & 0.15 & 3.28 & 0.044 \\
Error & 2.98 & 64 & 0.046 & - & - \\
Maximum Lower Jaw Angular Displacement (degree) & 0.00 & 2 & 0.00 & 0.074 & 0.929 \\
Error & 0.17 & 64 & 0.003 & - & - \\
Time to Maximum Lower Jaw Angular Displacement (ms) & 0.019 & 2 & 0.01 & 0.29 & 0.750 \\
Error & 2.12 & 64 & 0.033 & - & - \\
\hline
\end{tabular}

Table 5 shows the results of the Post-MANCOVAR Hypothesis Test to determine the relative contribution of temperature-effect to the variation of prey-capture kinematics between B. belizanus and C. urophthalmus across environmental temperature regimes. 


\section{Discussion}

Species that adapt to a wide range of environmental biotic and abiotic factors that are introduced into ecosystems beyond their native distributions establish invasive populations at a faster rate than those species with narrow environmental tolerance (Arthington \& Mitchell, 1986; di Castri, 1990; Sakai et al., 2001; Lee, 2002). Two tropical species, the pike killifish, B. belizanus, and the Mayan cichlid, C. urophthalmus, introduced into south Florida, USA in the 1950s and 1980s, respectively, are among the most dominant nonnative fish-species in the state (Belshe, 1961; Miley, 1978; Anderson, 1980; Kerfoot et al., 2011). Both species tolerate a wide range of environmental temperature $\left(9-30^{\circ} \mathrm{C}\right.$ for pike killifish and $15-39^{\circ} \mathrm{C}$ for Mayan cichlid) and salinity $(0-35 \mathrm{ppt}$ for pike killifish and 0->37ppt for Mayan cichlid) (Martinez-Palacios \& Ross, 1992; Stauffer \& Boltz, 1994; Chávez-López et al., 2005; Paperno, Ruiz-Carus, Krebs, \& McIvor, 2008; Schofield et al., 2009; Kerfoot et al., 2011; Kerfoot, 2012). Despite their contrasting feeding functional morphology and prey-capture behavior, there is an overlap in the species and size composition of the prey they consume (Harms, 2011; Young, 2011). Prey selectivity is dependent on the relative proportion of prey organisms in their environment (Harms \& Turingan, 2012). Thus, these nonnative fishes are well adapted to locally available prey resources; they are voracious, highly competitive predators in their invaded ecosystem (Turner \& Snelson Jr., 1984; Chávez-López et al., 2005; Bergmann \& Motta, 2005; Greven \& Brenner, 2008; Kerfoot et al., 2011; Kerfoot, 2012; Harms \& Turingan, 2012). The ability of pike killifish and Mayan cichlid to respond positively to the biological and physical conditions in their invaded ecosystems allows them to continually expand their nonnative range of distribution, especially in Florida, USA.

What is striking about the B. belizanus and C. urophthalmus is their equally successful invasion of Florida waters, yet each represent a different trophic niche as defined by their feeding functional morphology and behavior: B. belizanus has a specialist, piscivorous feeding mechanism whereas C. urophthalmus has the generalist-teleost feeding mechanism (Bergmann \& Motta, 2005; Hellig et al., 2010; Ferry-Graham et al., 2010). $B$. belizanus has evolved a unique feeding mechanism that is equipped with long oral jaws that can be opened widely to achieve a relatively large gape during prey-capture. It is also hypothesized that achieving a large gape is further facilitated by the presence of a premaxillomandibular ligament and a unique joint that allows postero-dorsal rotation of the premaxilla (Ferry-Graham et al., 2002; Porter \& Motta, 2004; Greven \& Brenner, 2008; Grubich, Rice, \& Westneat, 2008; Ferry-Graham et al., 2010). However, recent laboratory experiments concluded that $B$. belizanus was capable of feeding on non-fish prey, such as live ghost shrimp using its piscivorous-feeding mechanism and a stereotypical feeding repertoire (Harms \& Turingan, 2012). The relatively wide diet breadth of $C$. urophthalmus is consistent with having a generalized teleost feeding mechanism (Bergmann \& Motta, 2005; Young, 2011). It is conceivable that the interspecific variation in prey-capture kinematics between these two nonnative fishes is driven by the difference in the design of the feeding mechanism and behavior between species.

Having two model nonnative fish species with contrasting feeding mechanisms provides an opportunity to explore the generality of conclusions drawn from studies that investigate the effects of temperature on the performance of whole organisms, particularly aquatic poikilotherms such as fishes. Do temperature-induced effects on performance manifest themselves equally between generalist- and specialist-feeding nonnative fishes? Comparing consequences of temperature on performance between specialist- and generalist-nonnative species is important because it helps elucidate our understanding of how functional specialists keep up with generalists in performing challenging tasks such as capturing novel prey in invaded ecosystems. In addition, knowledge of how specialists and generalists respond to environmental temperature gives conservation biologists and ecologists the ability to understand important ecological and biological processes including range and rate of expansion of nonnative species in their invaded ecosystem.

Environmental temperature has consequent implications for aquatic-organismal performance because of temperature-induced effects on physiological and mechanical processes (Vogel, 1994; Hachachka \& Somero, 2002). For prey-capture in fishes the physiological effects of temperature are exhibited in the observed variation in the values of performance metrics (e. g., maximum gape, time to reach maximum gape and other kinematic variables) across different temperature treatments. Kinematics is largely driven by muscles, and it is well known that contractile properties of muscles are influenced by ambient temperature (Josephson, 1993; Kingsolver \& Huey, 1998; Johnston \& Temple, 2002). The mechanical effect of ambient temperature on organismal performance is rooted from the inherent effects of temperature on the dynamic viscosity of water (Vogel, 1994). In general, water viscosity increases with decreasing temperature; consequent drag on the feeding mechanism during prey-capture is also altered (Emlet \& Strathmann, 1985).

To date, there are two studies that addressed the effects of temperature on the feeding kinematics of teleost fishes 
(Wintzer \& Motta, 2004; DeVries \& Wainwright, 2006). In both studies, centrachid fishes Lepomis microchirus and Micropterus salmoides responded similarly to acute changes in environmental temperature. For example, time to reach maximum gape increased as the environmental temperature decreased (Wintzer \& Motta, 2004; DeVries \& Wainwright, 2006). In this study, regardless of the contrasting feeding mechanism of B. belizanus and C. urophthalmus, the kinematics of prey-capture in both nonnative fishes was largely unaffected by environmental temperature. We postulate that the disparate responses of the prey-capture kinematics to environmental temperature between the Wintzer and Motta (2004) as well as the DeVries and Wainwright (2006) studies and this study is a consequence of the temporal course of the temperature change. In the former studies, environmental temperature was altered acutely, by up to $6-9^{\circ} \mathrm{C}$ within an hour to ten hours, whereas in this study, temperature was raised from $20^{\circ} \mathrm{C}$ to $30^{\circ} \mathrm{C}$ at a rate of $1^{\circ} \mathrm{C}$ daily. In rapid or acute changes in temperature, such as those demonstrated by the former studies, fish may have not been given enough time to fully acclimate its physiological functions, thus the whole-organism-performance consequence of the environmental-temperature-induced physiological response may have been more severe. Whole-organism performance is unaltered by subtle changes in temperature (i.e., $1^{\circ} \mathrm{C}$ within 24 hours) even if the difference between the extreme ranges of temperature (e.g., $10^{\circ} \mathrm{C}$ difference between low and high temperature regimes) is considered high among physiologists (i.e., $\mathrm{Q}_{10}$ values). Therefore, it is imperative to consider the rate of change in temperature when quantifying the effects of environmental temperature on organismal performance. We propose that based on the invariant pattern of feeding kinematics across environmental temperature regimes observed in this study, nonnative fishes could better adapt to chronic changes in temperature.

\section{Acknowledgments}

The authors thank Chelsea Harms, Lisa Young, and Ben Compton for their assistance in capturing films, and Brian Bement for drawing Figure 1. Sigma Xi Scientific Research Society provided funding for this research.

\section{References}

Anderson, R. (1980). Geographic variation and aspects of the life history of Belonesox belizanus Kner (Pisces: Poeciliidae) from Central America. Northern Illinois University.

Arthington, A. H., \& Mitchell, D. S. (1986). Aquatic invading species. In: Groves, R. H., Burdon, J. J. (Eds.), Ecology of Biological Invasions (pp 34-53). New York, NY: Cambridge University Press.

Bacheler, N. M., Neal, J. W., \& Noble, R. L. (2004). Diet overlap between native bigmouth sleepers (Gobiomorus dormitory) and introduced predatory fishes in a Puerto Rico reservoir. Ecology of Freshwater Fish, 13(2), 111-118. http://dx.doi.org/10.1111/j.1600-0633.2004.00040.x

Baker, A. C., Starger, C. J., McClanahan, T. R., \& Glynn, P. W. (2004). Coral reefs: corals' adaptive response to climate change. Nature, 430, 741. http://dx.doi.org/10.1038/430741a

Belshe, J. F. (1961). Observations of an introduced tropical fish (Belonesox belizanus) in southern Florida. Coral Gables. University of Miami.

Bergmann, G. T., \& Motta, P. J. (2005). Diet and morphology through ontogeny of the nonindigenous Mayan cichlid 'Cichlasoma (Nandopsis)' urophthalmus (Günther 1862) in southern Florida. Environmental Biology of Fishes, 72(2), 205-211. http://dx.doi.org/10.1007/s10641-004-1480-1

Britton, J. R., Davies, G. D., Brazier, M., \& Pinder, A. C. (2006). A case study on the population ecology of a topmouth gudgeon (Pseudorasbora parva) population in the UK and the implications for native fish communities. Aquatic Conservation, 17(7), 749-759. http://dx.doi.org/10.1002/aqc.809

Charmantier, A., McCleery, R. H., Cole, L. R., Perrins, C., Kruuk, L. E. B., \& Sheldon, B. C. (2008). Adaptive phenotypic plasticity in response to climate change in a wild bird population. Science, 320(5877), 800-803. http://dx.doi.org/10.1126/science.1157174

Chavez-Lopez, R., Peterson, M. S., Brown-Peterson, N., Morales-Gomez, A. A., \& Franco-Lopez, J. (2005). Ecology of the Mayan cichlid, Cichlasoma urophthalmus, in the Alvarado Lagoonal system, Veracruz, Mexico. Gulf and Caribbean Research, 17(2), 123-131.

Clarke, A., \& Johnston, N. M. (1999). Scaling of metabolic rate with body mass and temperature in teleost fish. Journal of Animal Ecology, 68(2), 893-905. http://dx.doi.org/ 10.1046/j.1365-2656.1999.00337.x

Cossins, A. R., \& Bowler, K. (1987). Temperature biology of animals. New York, NY: Chapman and Hall (Methuen).

Crowder, L. B. (1984). Character displacement and habitat shift in a native cisco in Southeastern Lake Michigan: 
Evidence for competition? Copeia, 4(4), 878-883.

Davis, M. B., \& Shaw, R. G. (2001). Range shifts and adaptive responses to Quaternary climate change. Science, 292(5517), 673-679. http://dx.doi.org/10.1126/science.292.5517.673

DeVries, M. S., \& Wainwright, P. C. (2006). The effects of acute temperature change on prey capture kinematics in largemouth bass, Micropterus salmoides. Copeia, 2006(3), 437-444.

diCastri, F. (1990). On invading species and invaded ecosystems: the interplay of historical chance and biological necessity. In: di Castri, F., Hansen, A. J., \& deBussche, M. (Eds.), Biological Invasions in Europe and the Mediterranean Basin (pp. 3-16). Boston, MA: Kluwer Academic Publishers.

Douglas, M. E., Marsh, P. C., \& Minckley, W. L. (1994). Indigenous fishes of western North America and the hypothesis of competitive displacement: Meda fulgida (Cyprinidae) as a case study. Copeia, 1994(1), 9-19.

Emlet, R. B., \& Strathmann, R. R. (1985). Gravity, drag, and feeding currents of small zooplankton. Science, 228(4702), 1016-1017.

Ferry-Graham, L. A., Hernandez, L. P., Gibb, A. C., \& Pace, C. (2010). The unusual kinematics and jaw morphology associated with piscivory in the poeciliid, Belonesox belizanus. Zoology, 113(3), 140-147.

Ferry-Graham, L. A., Bolnick, D., I., \& Wainwright, P. C. (2002). Using functional morphology to examine the ecology and evolution of specialization. Integrative and Comparative Biology, 42(2), 265-277. http://dx.doi.org/10.1093/icb/42.2.265

Gillooly, J. F., Brown, J. H., West, G. B., \& Savage, V. M. (2001). Effects of size and temperature on metabolic rate. Science, 293(5538), 2248-2251. http://dx.doi.org/10.1126/science.1061967

Gozlan, R. E., St-Hilaire, S., Feist, S. W., Martin, P., \& Kent, M. L. (2005). An emergent infectious disease threatens European fish biodiversity. Nature, 435(1046), 1046. http://dx.doi.org/10.1038/4351046a

Green, B. S., \& Fisher, R. (2004). Temperature influences swimming speed, growth and larval duration in coral reef fish larvae. Journal of Experimental Marine Biology and Ecology, 299(1), 115-132. http://dx.doi.org/10.1016/j.jembe.2003.09.001

Greven, H., \& Brenner, M. (2008). Further notes on dentition and prey capture of the pike killifish Belonesox belizanus(Poeciliidae). Bulletin of Fish Biology, 10(1/2), 97-103.

Grubich, J. R., Rice, A. N., \& Westneat, M. W. (2002). Functional morphology of bite mechanics in the great barracuda (Sphyraena barracuda). Zoology, 111(1), 16-29. http://dx.doi.org/10.1016/j.zool.2007.05.003

Harms, C. A. (2011). Feeding versatility of the invasive pike killifish, Belonesox belizanus (Cyprinidontiformes: Poeciliida). Melbourne, FL. Florida Institute of Technology.

Harms, C. A., \& Turingan, R. G. (2012). Dietary flexibility despite behavioral stereotypy contributes to successful invasion of the functional-specialist pike killifish, Belonesox belizanus, in Florida, USA. Aquatic Invasions, Under Revision.

Hellig, C. J., Kerschbaumer, M., Sefc, K. M., \& Koblmüller. (2010). Allometric shape change of the lower pharyngeal jaw correlates with a dietary shift to piscivory in a cichlid fish. Naturwissenschaften, 97(7), 663-672. http://dx.doi.org/10.1007/s00114-010-0682-y

Herbing, I. (2002). Effects of temperature on larval fish swimming performance: the importance of physics to physiology. Journal of Fish Biology, 61(7), 865-876. http://dx.doi.org/10.1111/j.1095-8649.2002.tb01848.x

Hochachka, P. W., \& Somero, G. N. (2002). Biochemical Adaptation: Mechanisms and Processes in Physiological Evolution. Oxford, UK: Oxford University Press.

Hubbs, C. L. (1936). Fishes of the Yucatan Penisula. In: Cenotes of Yucatan (pp. 157-288). Carnegie Institute of Washington.

Hulsey, C. D. (2006). Function of a key morphological innovation: fusion of the cichlid pharyngeal jaw. Proceedings of the Royal Society B, 273(1587), 669-675. http://dx.doi.org/10.1098/rspb.2005.3375

Johnston, I. A., \& Temple G. K. (2002). Thermal plasticity of skeletal muscle phenotype in ectothermic vertebrates and its significance for locomotory behavior. Journal of Experimental Biology, 205, 2035-2322.

Josephson, R. K. (1993). Contraction dynamics and power output of skeletal muscle. Annual review of physiology, 55, 527-546. http://dx.doi.org/10.1146/annurev.ph.55.030193.002523

Kerfoot, J. R. (2012). Thermal tolerance of the invasive Belonesox belizanus, pike killifish, throughout ontogeny. 
Journal of Experimental Zoology, 317(5), 266-274. http://dx.doi.org/10.1002/jez.1720

Kerfoot, J. R., Lorenz, J. J., \& Turingan, R. G. (2011). Environmental correlates of the abundance and distribution of Belonesox belizanus in a novel environment. Environmental Biology of Fishes, 92(1), 125-139. http://dx.doi.org/ 10.1007/s10641-011-9822-2

Kingsolver, J. G., \& Huey, R. B. (1998). Evolutionary analyses of morphological and physiological plasticity in thermally variable environments. American Zoologist, 38(3), 545-560. http://dx.doi.org/10.1093/icb/38.3.545

Lee, C. E. (2002). Evolutionary genetics of invasive species. Trends in Ecology \& Evolution, 17(8), 386-391. http://dx.doi.org/10.1016/S0169-5347(02)02554-5

Lee, C. G., Farrell, A. P., Lotto, A., MacNutt, M. J., Hinch, S. G., \& Healey, M. C. (2003). The effect of temperature on swimming performance and oxygen consumption in adult sockeye (Oncorhynchus nerka) and coho (O. kisutch) salmon stocks. Journal of Experimental Biology, 206, 3239-3251. http://dx.doi.org/10.1242/jeb.00547

Loftus, W. F. (1985). Probable establishment of the Mayan cichlid, Cichlasoma urophthalmus, in extreme southern Florida. Florida Scientist, 48, 33.

Malek, R. L., Sajadi, H., Abraham, J., Grundy, M. A., \& Gerhard, G. S. (2004). The effects of temperature reduction on gene expression and oxidative stress in skeletal muscle from adult zebrafish. Comparative Biochemistry and Physiology Part C: Toxicology \& Pharmacology, 138(3), 363-373. http://dx.doi.org/10.1016/j.cca.2004.08.014

Martinez-Palacios, C. A., Ross, L. G., \& Rosado-Vallado, M. (1990). The effects of salinity on the survival and growth of juvenile Cichlasoma urophthalmus. Aquaculture, 91(1-2), 65-75. http://dx.doi.org/10.1016/0044-8486(90)90177-O

McKinney, M. L., \& Lockwiid, J. L. (1999). Biotic homogenization: a few winners replacing many losers in the next mass extinction. Trends in Ecology \& Evolution, 14(11), 450-453. http://dx.doi.org/10.1016/S0169-5347(99)01679-1

Miley, W. W. (1978). Ecological impact of the pike killifish, Belonesox belizanus, Kner, (Poeciliidae) in southern Florida. Boca Raton, FL: Florida Atlantic University.

Miller, R. R. (1966). Geographical distribution of Central American freshwater fishes. Copeia, 1966(4), 773-802.

Mooney, H. A., \& Cleland, E. E. (2001). The evolutionary impact of invasive species. Proceedings of the National Academy of Sciences, 98(10), 5446-5451. http://dx.doi.org/10.1073/pnas.091093398

Moyle, P. B., \& Light, T. (1996). Biological invasions of fresh water: empirical rules and assembly theory. Biological Conservation, 78(1-2), 149-161. http://dx.doi.org/10.1016/0006-3207(96)00024-9

Ogutu-Ohwayo, R. (1990). The decline of the native fishes of lakes Victoria and Kyoga (East Africa) and the impact of introduced species, especially the Nile perch, Lates niloticus, and the Nile tilapia, Oreochromis niloticus. Environmental Biology of Fishes, 27(2), 81-96. http://dx.doi.org/10.1007/BF00001938

Paperno, R., Ruiz-Carus, R., Krebs, J. M., \& McIvor, C. C. (2008). Range expansion of the Mayan cichlid Cichlasoma urophthalmus (Pisces, Cichlidae), above 28N latitude in Florida. Florida Scientist, 71(4), 293-303.

Perry, W. L., Lodge, D. M., \& Feder, J. L. (2002). Importance of hybridization between indigenous and nonindigenous freshwater species: an overlooked threat to North American biodiversity. Systematic Biology, 51(2), 255-275. http://dx.doi.org/10.1080/10635150252899761

Pimentel, D., Zuniga, R., \& Morrison, D. (2005). Update on the environmental and economic costs associated with alien-invasive species in the United States. Ecological Econonmics, 5522(3), 273-88. http://dx.doi.org/10.1016/j.ecolecon.2004.10.002

Porter, H. T., \& Motta, P. J. (2004). A comparison of strike and prey capture kinematics of three species of piscivorous fishes: Florida gar (Lepisosteus platyrhincus), redfin needlefish (Strongylura notata) and great barracuda (Sphyraena barracuda). Marine Biology, 145(5), 989-1000. http://dx.doi.org/10.1007/s00227-004-1380-0

Rahel, F. J. (2007). Biogeographic barriers, connectivity and homogenization of freshwater faunas: it's a small world after all. Freshwater Biology, 52(4), 696-710. http://dx.doi.org/10.1111/j.1365-2427.2006.01708.x 
Rome, L. C., Swank, D. M., \& Coughlin, D. J. (2000). The influence of temperature on power production during swimming. II. Mechanics of red muscle fibers in vivo. Journal of Experimental Biology, 203,333-345.

Rome, L. C., \& Sosnicki, A. A. (1990). The influence of temperature on mechanics of red muscle in carp. Journal of Physiology, 427, 151-169.

Rosen, D. E., \& Bailey, R. M. (1963). Thepoeciliid fishes (Cyprinodontiformes): their structure, zoogeography, and systematics. Bulletin of the American Museum of Natural History, 126, Article 1.

Sakai, A. K., Allendorf, F. W., Holt, J. S., Lodge. D. M., Molofsky, J., With, K. A., ... Weller, S. G. (2001). The population biology of invasive species. Annual Review of Ecology and Systematics, 32, 305-332.

Sato, M., Kawaguchi, Y., Nakajima, J., Mukai, T., Shimatani, Y., \& Onikura, N. (2010). A review of the research on introduced freshwater fishes: new perspectives, the need for research, and management implications. Landscape and Ecological Engineering, 6(1), 99-108. http://dx.doi.org/10.1007/s11355-009-0086-3

Schofield, P. J., Loftus, W. F., \& Fontaine, J. A. (2009). Salinity effects on behavioural response to hypoxia in the non-native Mayan cichlid Cichlasoma urophthalmus from Florida Everglades wetlands. Journal of Fish Biology, 7(6), 149-156. http://dx.doi.org/10.1111/j.1095-8649.2009.02192.x

Shafland, P. L., \& Pestrak, J. M. (1982). Lower lethal temperatures for fourteen nonnative fishes in Florida. Environmental Biology of Fishes, 7(2), 149-156.http://dx.doi.org/10.1007/BF00001785

Singh, A. K., Pathak, A. K., \& Lakra, W. S. (2010). Invasion of an exotic fish - common carp, Cyprinus carpio L. in the Ganga River, India and its impacts. Acta Ichthyologica Et Piscatoria, 40(1), 11-19.

Stauffer, J. R., \& Boltz, S. E. (1994). Effect of salinity on the temperature preference and tolerance of age-0 Mayan cichlids. Transactions of the American Fisheries Society, 123(1), 101-107. http://dx.doi.org/10.1577/1548-8659(1994)123<0101:EOSOTT $>2.3 . C O ; 2$

Turner, J. S., \& Snelson, Jr., F. F. (1984). Population structure, reproduction and laboratory behavior of the introduced Belonesox belizanus (Poeciliidae) in Florida. Experimental Biology of Fishes, 10(1-2), 89-100. http://dx.doi.org/10.1007/BF00001665

Vogel, S. (1994). Life in Moving Fluids, the Physical Biology of Flow (2nd ed). Princeton, NJ: Princeton University Press.

Watabe, S. (2002). Temperature plasticity of contractile proteins in fish muscle. Journal of Experimental Biology, 205, 2231-2236.

Weinstein, M. R., Litt, M., Kertesz, D. A., Wyper, P., Rose, D., Coulter, M., ... Low, D. E. (1997). Invasive infections due to a fish pathogen, Streptococus iniae. New England Journal of Medicine, 337, 589-594.

Wintzer, A. P., \& Motta, P. J. (2004). The effects of temperature on prey-capture kinematics of the bluegill (Lepomis macrochirus): implications for feeding studies. Canadian Journal of Zoology, 82(5), 794-799. http://dx.doi.org/10.1139/z04-061

Young, L. E. (2011). Variation in feeding ecomorphology between northern and southern Florida subpopulations of the invasive Mayan cichlid, Cichlasoma urophthalmus. Melbourne, FL. Florida Institute of Technology. Retrieved from http://myfwc.com/wildlifehabitats/nonnatives/freshwater-fish 